\title{
The Quest for Freedom in Tennessee Williams' The Rose Tattoo and Sweet Bird of Youth
}

\author{
Novita Dewi \\ English Language Studies, Sanata Dharma University \\ novitadewi9@gmail.com
}

\begin{abstract}
This paper examines the interface of economic hardship, sexual repression, and fear of aging in Tennessee Williams' plays of the 1950s. Set in modern capitalist society of America, The Rose Tattoo (1955) and Sweet Bird of Youth (1959) depict the characters who are thwarted in their search for freedom that can be equated with the celebration of material prosperity and eternal youth. Using Eric Fromm's view of freedom-as-frightful in modern society, the discussion will reveal the entrapment of self-deception in the characters' unrealistic hope to stay young and productive in a commercialised society where sex is a commodity.
\end{abstract}

Keywords: economic hardship, sexual repression, fear of aging

\section{Introduction}

Numerous critics have labelled Tennessee Williams an erotic writer and a disciple of D. H. Lawrence because of his intense preoccupation with sex in most of his plays. Hirsch (1979: 4), for example, says that Williams was a "confused moralist", who believed that sex was something like "grace", and at the same time "impure". In discussing Sweet Bird of Youth, Falk (1961) contends that Williams' creativity began to decrease with the appearance of this sexually obsessive play. Conversely, Bigsby (1984) argues that the artistic impulse in Williams' early works did not wane, but instead, sexuality became a creative energy in his later plays. In particular, Siegel (2005) claims that sexual repressions in some plays are but manifestations of disturbing mother-son relationship.

However, in focusing only on sexual themes, a great deal of Williamsian scholarship has overlooked the wider social implications that give rise to sexual expression as well as repression. The sexstereotyped characters in Williams' plays are all absorbed in a pursuit of freedom, and this aspect has not been well documented. Throughout his plays, Williams portrays characters whose sex drive is born largely out of their desire to free themselves from other restrictions. Psychoanalysis assumes that the urge for sexual action is inextricably linked to the drive for power which is often synonymous with freedom (Benson, 1974: 211). Thus freedom is related to the ability to achieve one's goal, one's happiness, and one's pleasure; and sex is only one instance of expression and fulfilment on the road to success. In the modern capitalist society which forms a backdrop for Williams' plays, freedom is often materialized in the accumulation of wealth and power (potency).

It is not difficult to understand the dominant mood in Williams' characters in their search for freedom, as it is but representation of American principle deeply taken root in society since the day of the Pilgrim Fathers (Kennedy, 1993: 67). Having left their country for religious freedom, the early European settlers found in the New World not only "The City on the Hill", but also a paradise on earth with unceasingly 
abundant wealth for whoever worked hard. This optimism grew stronger about two centuries later by the statement set forth in the Declaration of Independence: "that all men are equal; that they are endowed by their Creator with certain inalienable rights; that among these, are Life, Liberty, and the Pursuit of Happiness" (cited in Blum, 1993: 908). This liberating statement, evolving out of the freedom aspirations of the early settlers, has formed the basis for an ideology involving freedom. Freedom in modern America has come to mean freedom in every respect. Hence, a myth has developed that in this free, rich, and strong country, any hardworking individual is sure to succeed in life.

It was only in the 1920s and culminating in the Depression of the thirties that Americans began to realize that they had been building a false heaven. It was not until the Depression that the myth of the American Dream operated paradoxically - both as an agent of progress and as a force of destruction. The considerable advancement in business and industry in the twenties had created a materialistic and alienated society who cherished enterprise, comfort, commercialism, and individualism. Celebrities like sportsmen and Hollywood stars were American heroes and heroines; and the middle-class were avid consumers of advertise products with which they emulated their idols: "ingredients of the good lifehealth in orange juice, cleanliness in soap, popularity in deodorants, romantic love in voguish clothes" (Blum, 1993: 639).

Such concern for physical appearance, accordingly, helped explain the changing attitude of the Americans towards sex. The availability of tabloid, magazine, film, and other media to delight people especially the youngsters with cheap sensationalism pertaining to sex quickly encouraged promiscuity. People wrongly interpreted Freudian psychoanalysis as license for sexual freedom. Such is society's rebellion against the puritanical views of sex.

Meanwhile, some nonconformists loathed the futility and emptiness of the business world. They expressed their disappointment with the materialistic society through art as by means of protest music they named "Jazz", hence the term also used by F. Scott Fitzgerald to characterize Literature of the Jazz Age that was rife with themes of alienation. To mention in passing, Fitzgerald's own novel Tender is the Night, like most of Williams' plays, depict the correlation between sexual potency and class prerogatives (Bigsby, 1986: 86). The appearance of sexually subversive literary works here showed people's anxiety and discontent of the troubled times whereby their dreams were inevitably shattered by economic disaster.

Williams wrote about a society whose faith in the unlimited freedom to strive for the material success was dashed by the harsh realities in the modern world. The work ethic of the nineteenth century, i.e. there is a moral, religious value in working hard was distorted in modern American capitalism (Greenfield, 1982: 8). Being brought up to believe that their country is a fountain of wealth, the Americans were hardly prepared to face the truth: queuing for bread, homelessness, unemployment, and various calamities. "Poverty, stagnation, pessimism, imperfection", says Choudhuri, "were unAmerican words" (1979: 35). With the Great Depression, however, Americans had to enlist these words into their vocabulary whilst admitting that there were indeed limits to success.

This paper will explore the varied notions of freedom sought after by the characters in Williams' The Rose Tattoo (1951) and Sweet Bird of Youth (1959). Selection of the two plays is under an assumption that the period between the 1940s and late 1950s marks the peak of Williams' creativity and achievement. In Memoirs, the playwright admits that after this period, came his turbulent years, especially during the sixties, where he was under treatment for paranoia and depression (Williams, 1975: 208). Besides, variations in search of freedom are most clearly displayed in these plays. The discussion that follows will focus on how the characters are struggling to gain their freedom, but are often failed in their attempts given the uncontrollable social and psychological 
forces. A rough division of three types of freedom in the two plays will be made: (1) freedom from socioeconomic pressure, (2) freedom from sexual repression, and (3) freedom from the fear of aging.

\section{Freedom from Socioeconomic Pressure}

"To be free is to have achieved your life", says Williams in his Memoirs, "It means the freedom of being" (1975: 230). In the "Foreword" to Sweet Bird of Youth, the playwright also speaks of writing as his sanctuary - an escape from his troubled years as an effeminate boy of 14 in search of freedom to be what he wants to be. Recently, Kolin (2014) shows that Williams' correspondence with Truman Capote about his doubt about casting for The Rose Tattoo may shed light on his gay relationship. For Williams then, freedom is the attainment of self-identity. Just as the celebration of freedom is central to Williams' life, so do the characters in his plays struggle in their journey for self-hood or, as Jackson puts it, "pursu[ing] their odyssey" (1966: 86).

Indeed, the characters' struggle to claim who they are cannot be separated from the fact that they were all born into the materialistic grasping society of America. Written against the background of the 1930s Great Depression, his plays portray the ways in which ideology surrounding the notion of success had elevated material prosperity and had marginalized the weak, the rejects, and the ostracized of society.

To begin with Serafina Delle Rose in The Rose Tattoo, this Italian-descent woman is cast like any other Southerner women typical of Williams' female characters with their high aspirations of being upwardly mobile. Set in a Sicilian Village on the Gulf Coast between New Orleans and Mobile, the play focuses on Serafina, who terribly shocked by the death of her husband Rosario, leads a life of selfindulgence. She isolates herself in her room, mourns over the dead husband whose ashes are kept in an urn against the law of the Catholic Church; and becomes overprotective to her daughter. The moment she discovers her husband's infidelity, she gives up the three-year devotion and falls in the rams of a trucker whose body resembles her husband's. Bewildered by her own hypocrisy, she finally gives consent to her passion-burnt daughter to meet her boyfriend in a hotel room.

Married to an Italian nobility at the age of 14 to lift her social status, Serafina feels fortunate not to work like other peasant girls saying "I married a baron when I didn't have shoes!" (Williams, 1955: 84). Rosario with his baron status, nevertheless, does very little to upgrade their economic situation for which reason they left for America:

\section{SERAFINA: Tonight is the last time he does it! Tomorrow he quits hauling stuff for the Brothers Romano! He pays for the 10-ton truck and works for himself. We live in dignity in America, then! Own truck! Own truck! Own house! And in the house will be everything electric! Stove - deep-freeze-tutto! (Williams, 1955: 7)}

In keeping with the economic demand, Serafina is willing to take up sewing for additional income as part of her effort to pursue her dream - freedom from want. She is fast, serious seamstress except for the days when rumours about her husband's affair reaches her and increasingly becomes unbearable. She can finish Estelle Hohengarten's order for the rose-coloured silk shirt in one day for twenty-five dollars, five times as much as the normal cost. Under emotional pressure and complaints of anxious neighbours, Serafina can complete their daughters' graduation outfits. She, too, can recognize the customer who does not give her sufficient payment for the work and fight for her rights. She can finish Flora's blouse under time and emotional pressure in order to cash on more money. Serafina is money-conscious; and for her business is business, hence her insistence to charge Alvaro's phone call despite the young man's charm.

Life is hard for Alvaro Mangiacavallo the truck driver to whom Serafina is attracted. He is the breadwinner of a family consisting of three dependants: a spinsterish sister, a 
gambling crazed grandmother, and a jobless brother - all with bad drinking habits. Alvaro's daily earnings hardly makes both ends meet, while his boss can legally cut off his wage or even fire him at any time. Williams clearly depicts the cruelty of American industrialized society. To Alvaro, then, Serafina is a God-sent-Angel to release him from his financial as well as sexual burdens, for she is the "sensible older lady" who has "a well-furnished house and profitable little business" (Williams, 1955: 5). Likewise, Alvaro is the sexual liberator for Serafina who "can't swallow [her] heart" (Williams, 1955: 7). Their relationship is that of a business transaction. In mercantile society as such, complementary profitable business can be seen as an instrument to freedom.

In Sweet Bird of Youth, economic pressure is also the motive. Although Goldstein (1965: 33) argues that Williams' chief concern in this play is not greed but desire for eternal youth, the quest for youth itself is closely related to greed. Referred to as "glossy shocker about sex and politics" (Hirsch, 1979: 60), the play tells of Princess Kosmonopolis aka Alexandra del Lago, a retired actress and her gigolo Chance Wayne, a 29-year-old actor with slim chance of success. Both cannot accept growing old because their livelihood depends on age and appearance. Youth in industrialized America is a commodity while age is unproductive and therefore devalued. Chance's dream of freedom is to lead a good life with pleasure and gaiety for which reason he avoided "the goddam routine, discipline" of the military service (Williams 1959; rpr. 1978: 46) and prefer to move from hotel to hotel to entertain lonely women. Scene 2 of the play, for instance, opens with the Princess signing a cheque for Chance's love making.

In commenting on the futility of industrialized society, the play includes smuggling and blackmailing in the narrative. Chance blackmails the Princess over her involvement in the drug trade, although the motive of his threats is pave his way to the film world. Believing that success is purchasable, he says:
Patroness! Agents! Producers! She hasn't been seen much lately, but still has influence, power, and money - money that can open all doors. That I've knocked at all these years till my knuckles are bloody (Williams, 1978: 75).

Neither Chance nor Princess Kosmonopolis realize that their talents are limited. They both are accustomed to earning money easily by selling their bodies. Now that their assets begin to decline, they are not ready to change professions for they have neither skills nor determination to try their hands at different jobs. Given that change and novelty become the rule of the game in a competitive society, the lack thereof hampers their road to economic freedom.

\section{PRINCESS: Stars in retirement sometimes give acting lessons. Or take up painting, paint flowers on pots, or landscapes. I could have painted the landscapes of the endless, withering country in which I wandered like a lost nomad. If I could paint deserts and nomads, if I could paint...hahaha...(Williams, 1978: 33).}

Thus, to varying degrees, the characters in The Rose Tattoo and Sweet Bird of Youth are crushed in their ambitions to pursue their freedom. In times of economic depression, they become weak, vulnerable, and easily frustrated. In their description of the entanglement between personal problems and economic imbroglios, Williams' plays show that the American pursuit of Happiness, in this case money, has destroyed the social actors. The next section is to further discuss how these social actors also strive to pursue freedom by means of money's complimentary object named sex.

\section{Freedom from Sexual Repression}

In Freud on Broadway, Siever (1970) claims that sex is neither daring nor shocking a theme in a play by the thirties because of the changing attitude of the Americans. The Rose Tattoo was set in the preceding decade, but sexual freedom is the theme at the heart of the play. The female characters in the play come across as preoccupied by sexual 
anxiety. Aphrodisiacs are purchasable from Assunta; and the fattuchiere is on her way to her clients who need sexual therapy. Estelle Hohengarten has a rose tattoo and a rosecoloured shirt made to cherish her passion with Rosario the man she is flirting with. The conversation between Bessie and Flora is rich in sexual connotations with which, according to Spoto (1985: 171), one important audience at the opening night of The Rose Tattoo, Mrs. Edwina Dakin, was reportedly embarrassed by the blatant talk of sex and love-making in the play. Like mother like daughter, Rosa Delle Rose is depicted as a young girl who cannot wait to jump at the first opportunity to make love with her boyfriend. It would seem that for these women, celebrating sexual freedom is the order of the day.

Serafina used to express her sexual yearnings by means of her union with Rosario. In the play the sanctity of the union is metaphorically presented through children's playing, goat chasing, and intrusion of the unwanted Strega. Only Serafina's husband can release her tension and make her feel alive: "Oh, it's so wonderful, having two lives in the body, not one but two! I am heavy with life, I am big, big, big with life" (Williams, 1955: 9). She is so sexually driven that she is able to precisely count as much as 3,480 times of love making since the day they were married.

The need of freedom from sexual repression is even heightened when Serafina becomes a widow, but she insists on maintaining her purity until she meets Alvaro. Having confessed to Father De Leo that she does not need any friends, she withdraws herself and lives like a recluse in her room with the dummies. She maintains that the dummies make her companions for the mannequins do not argue or disrupt her to do what she wants. What she needs is someone like Assunta who sometimes comes to visit to listen to the widow's outpouring of romantic stories about Rosario. Serafina is seen so furious when two nit-wits, Flora and Bessie talk dirtily about male-female relations in her "Catholic house" where she sets a shrine of Rosario's ashes and a burning candle before the statue of the Virgin Mary (Williams, 1955: 36).
As sensually as her mother is, Rosa Delle Rose is seen as "sort of wild" by her American boyfriend sailor, Jack Hunter (Williams, 1955: 41). In agreement with Henry Hopkin's observation, Falk (1961: 98) says that Williams often contrasts the cool AngloSaxons with the sexually exciting Italians in his plays. When Serafina locks up Rosa's clothes to prevent her from going out with Jack, the 15-year-old girl, much to the surprise of the neighbours, stands naked at the window calling out any passers-by for help. Added to this rebellious act that does not work well, Rosa puts mercurochrome on her wrist to fool her mother into thinking that she hurt herself.

To portray the warm-blooded Rosa, Williams has this character perform some seductive overtures such as dancing too close to Jack, teaching him the word "bacio", and "raining kisses upon him till he forcibly removes her face from his" (Williams, 1955: 46). Accentuation of her wild portrayal is clear in Act 3 Scene 2 when she tries to seduce Jack who is too love-sick to conquer Rosa's wild impulse.

Jack [breathlessly]: In all my life, I never felt nothing so sweet as the feel of your little warm body in my arms...[He breaks away and runs toward the road. From the foot of the steps he glares fiercely back at her like a tiger through the bars of a cage] (Williams, 1955: $132-3$ ).

Rosa is thus the instigator to incite Jack's repression. When she confronts the young sailor that sexual intimacy does not mean too much to him, Jack has this to say:

Look! Look at my knuckles! You see them scubs on my knuckles? You know how them scubs got there? They got there because I banged my knuckles that hard on the deck of the sailboat (Williams, 1955: $130-1$ ).

Jack is worsened by the promise he has made to his mother not to yield to sexual desire. "I feel like a - heel", he regretfully says, "I feel like a rotten heel!" (Williams, 1955: 126). His strict mother hampers his way to freedom. 
In comparison to Jack's, Alvaro's road to freedom from sexual anxiety is much smoother. To Alvaro, sex is "the one that every man's got, his biggest expense" (Williams, 1955: 106). As it happens, this clown-faced truck driver meets a woman who is willing to cover the expense, In return, Alvaro offers her "love and affection" because he does not have anything else to trade with "on hot or cold days in his lonely world" (Williams, 1955: 94). Alvaro manages to convince Serafina about her late husband's infidelity, i.e. his flirtation with Estelle. To get even, Serafina pursues her freedom with the newly found lover. Alvaro pretends to leave Serafina's house after dinner to avoid the neighbours' suspicion only to come back not long after to have sex all night with the hostess. Alvaro's presence, to some extent, also liberates Rosa's repression. Baffled by her own hypocrisy, Serafina allows Rosa to date Jack.

The bed is mythologized as the mark of sexual happiness in the Rose Tattoo. Similarly, the setting that opens and ends Sweet Bird of Youth is also a bed in a hotel room. But in this play, the bed symbolizes the sexual desperation of the characters. Accused of giving his girlfriend Heavenly Finley a venereal disease, Chance is under threat of castration from Heavenly's father, Boss Finley, the powerful businessman in St. Cloud. The playwright paints a dark picture of sex by also bringing into his play ovariectomy, abortion, incest, impotency, obsession with chastity, hypersexuality, nudity, the mistress, the courtesan, the prostitute, and the gigolo. Had Williams written the play in the late 80s, he would have included AIDS and HIV as well. Praising sex in hymns, the characters all sing a false note. In their search for freedom, the characters are thwarted because their version of freedom is proved fallacious.

Princes Kosmonopolis construes life as synonymous with unceasing, purchasable sexual journey. In Act 1, Scene 1, she reveals that she once married to "a great merchant prince" who taught her how to deal with money" (Williams, 1978: 41). She applies this business sense to making sex a transaction: given that age gradually deteriorates her; and she cannot live without sex, she buys it from gigolos. Added to her sexual needs is the Princess' frequent and regular intake of oxygen which is metaphorically associated with her struggle to breathe the air of freedom:

PRINCESS: No mention of death, never, never a word on that odious subject. I've been accused of having a death wish but I think it's life that I wish for, terribly, shamelessly, on any terms whatsoever. When I say now, the answer must not be later. I have only one way to forget these things I don't want to remember and that's the act of love-making. That's the only dependable distraction so when I say now, because I need that distraction, it has to be now, not later. (Williams, 1978: 41)

Like the Princess, Chance takes sex as the highest priority in life: "Maybe the one I was truly meant for, love-making..." (Williams, 1978: 45). Believing that he was born to make love, Chances challenges Heavenly's father whom the younger man accused of being sexually jealous and speaking the language of hatred. However, Chance fails to save his emotionally and physically neutered girlfriend. Having been infected with disease by Chance, Heavenly is too freakish to stand up to her father as to get "married for love" the way her father did (Williams, 1978: 63).

Thus, almost all characters are portrayed in their futile entanglement with sex. As for Boss Finley, his self-proclaimed mission is to save the Southerners' purity in race and religion. This character's puritanical hypocrisy is depicted first, by his keeping of a mistress Miss Lucy who turns her back on him when scrawling graffiti in ladies room about Finley's impotency after she gets a diamond ring. In today's context, SchulteSasse (1999) likens Finley's priggish morality to the Americans' demand for Clinton's impeachment after his affair with Monica Lewinski. Second, Boss Finley becomes even more sexually repressed because, unconsciously, he is attracted to his own daughter who brings him back the memory of his dead wife, hence some critics' claims of the play's theme of incest (e.g. D. Williams 
and Mead, 1983: 221; Bigsby, 1984: 154). To escape from sexual repression, Finley expresses what Chance called "sex envy" (Williams, 1978: 53) by his sadistic attempts to emasculate others including his children. For instance, he overprotects not only Heavenly but also Tom Junior his son. Angered by his father's fake morality, the frustrated Tom perversely sows his wild oats. Tom becomes a womanizer to whom Chance can give "the price of any whore in St. Cloud" (Williams, 1978: 90).

By way of conclusion, The Rose Tattoo and Sweet Bird of Youth give us portraits of the losers in their pursuit of freedom to satisfy their bodily hunger. Through these plays, Williams laments the restless seekers of physical gratification in American commercialized society where sex is often bought and sold. The characters exaggerate and see the horrors of sex deprivation; and they are often trapped in their false hope of obtaining eternal youth, which is regarded in society as being indispensable for sexual fulfilment. It is to the quest of eternal youth that the next section now turns.

\section{Freedom from the Fear of Aging}

The fear of aging is an Adamic trait that becomes a common attitude of the Americans whose myth of the New Eden on earth allows them to cling to the belief that everything is perpetual:

America was supposedly the location of the mythical fountain of youth and eternal life. And the worship of young life in a young continent is traditional and psychologically acceptable (Pradhan, 1978: 52).

The denial of age reflects the human beings' reluctance to face the passing of time as shown in the characters of the two plays under discussion. They are all helpless to defeat, to use Chance Wayne's words, "the enemy of time" (Williams, 1978: 110).

Time is an incomprehensible concept for the characters in The Rose Tattoo. Confronting Assunta the herb seller, Serafina says: "No, the clock is a fool. I don't listen to it.
My clock is my heart and my heart don't say tock-tick, it says love-love!" (Williams, 1978: 8). Denying that time does pass by, Serafina only admits the existence of the days of the pass, i.e., the days of romance with Rosario. The present reality is a threat to her. She prefers dying to aging due to her conviction that youth can be separated from physical beauty. Serafina thus neglects her appearance and ignores men upon the death of her notso-loyal husband. Like other Williamsian female characters, Serafina equates cessation of her sexual fulfilment with death itself. She hides herself in the sewing room and has no intention to live until she finds a new life in Alvaro the born-again Rosario. Critics have observed the symbolic meaning of the mannequins in her room where one dummy is clad in a colourful bridal gown, the other in a sombre and gloomy outfit of a widow. Boxill (1987: 125), to mention one, concurs that Williams uses this symbolism to reinforce the passion-death conflict between Eros and Thanatos.

Meanwhile, for Rosa Delle Rose, time is chasing her. Like her mother, Rosa does not believe in a second chance when Jack refuses to intimate physically with her. The young girl says: "No, but - I think it could just happen once, and if it don't happen that time, it never can - later..." (Williams, 1955: 130). Although in the end Serafina gives Rosa permission to go out with Jack, she fails to give her daughter a wrist-watch for graduation gift. The playwright uses this iconic item to symbolise the desire to escape from time.

In Sweet Bird of Youth, Princess Kosmonopolis' dream is to stay young forever and presentable to live in the film world. Age and appearance, among other things, are two significant assets to her career. Accordingly, she is aware that "the legend of Alexandra del Lago couldn't be separated from an appearance of youth" (Williams, 1978: 32). She reveals to Chance how disappointed and terrified she is upon noticing that the camera scarcely conceals the disappearance of youth from her face. Although she is capable of anticipating and admitting the end of her career, her excitement upon receiving the 
happy news about the box-office record of her movies can barely overcome her anxiety.

In contrast to the Princess who is quick to realize her inability to defeat time, Chance Wayne is made blind by his own dream of success. He is reluctant to admit that something is indeed lost in him, taken away by time. "BEAUTY! Say it! Say it!", the Princess tries to convince him, "What you had was beauty! I had it! I say it with pride, no matter how sad, being gone, now" (Williams, 1978: 44). Despite his fear, Chance continues to chase his freedom. His one ridiculous attempt, for instance, is to take chance in a talent-scouting. In his 29, Chance is not young any more for an artist, to say nothing of the fact that he once failed to recite part of his lines. Obsessed by his ambition to become an actor, he is being unreasonable: no talentscouter talent scouts her/himself, hence his plan to entitle his film "Youth". Chance takes every chance to prostitute himself to anyone who can help him chase his dream.

As for Heavenly Finley, she also tries to escape from the ghost of growing old. She comes across as very depressed and withdrawn. This love object of Chance is crippled by the ovariectomy operation that is a shocking threat to her womanhood. She says:

Ifelt worse and embarrassed when I found out that Dr. George Scudder's knife had cut the youth out of my body, made me an old childless woman. Dry, cold, empty, like an old woman. I feel as if I ought to rattle like a dried-up vine when the Gulf wind blows... (Williams, 1978: 65 - 6)

Here we see that Heavenly joins the parade of those who are in fear of old age, because such is seen as being unproductive. Thus, they make their best efforts to invest themselves in an unrealistic hope as well as a trap of selfdeception to remain young. Nevertheless, as argued by Tejaswani (2013), Heavenly and Chance strengthen their love to each other through time.

In sum, The Rose Tattoo and Sweet Bird of Youth present the American imagination of eternal youth through the characters who cannot accept growing old. Old age hampers their access to such physical pleasure as sex. They hold on to the illusion of eternity so strongly that they become desperate when the real world is not what they believe to be. Both plays reflect modern society where there is a quest for youth, hence the denial of age and death.

\section{Conclusion}

The rise of modern capitalist society opens up door for the expansion of people's personal freedom, but at the same time it may result in economic competition alongside its impact namely social inequalities. In Beneath the Mask, Christopher Monte (1987: 432) borrows the view of Eric Fromm on "freedom as frightful" in modern society as follows:

The existence of contemporary people is marked by aloneness, fear, and bewilderment. Their freedoms are not satisfying, they are frightful. Though each is totally an individual, contemporary persons are also sometimes totally isolated. In short, contemporary people do not cherish their own individuality, their own independence. They flee from their own freedom.

This paper has shown that Tennessee Williams writes about the American society whose faith in the unlimited freedom to strive for material and physical success was dashed by the harsh realities in the modern world where youth and good look are commodities. Williams' characters mostly belong to a less financially favoured class who can be easily defeated in their search for freedom that can be equated with the celebration of material prosperity and eternal youth. Thanks to the Great Depression that the modern society operates under a system whereby this credo is put into practice: Grab the money honestly if you can, and dishonestly if you have to.

In the Rose Tattoo, Serafina Delle Rose's husband was killed when he smuggled drugs under his banana truck. Her new object of interest Alvaro Mangiacavallo fought with a salesman, got sacked by his boss, and simplified his economic problem by clinging to the more financially stable woman. In 
Sweet Bird of Youth, Chance Wayne complains that the Korean war and economic disaster hampers both his career prospect and sexual freedom. Thus, freedom spells fear for the characters who share the wish to liberate themselves.

This paper has also shown that their search for financial freedom is corollary to their natural and inborn impulse, i.e. sexual starvation from which they try to escape to no avail. In their struggle to free themselves from sexual repression, the female characters appear stronger yet victimised and condemned in male-constructed society (Jackson, 1966; Scanlan, 1978; Timpane, 1989, etc.) Lou Benson is right to say that women are expected to be (sexually) attractive in order to be identified as woman (and thus she becomes an object of men's desire); on the contrary, if she is not sexually desirable, she is regarded as merely a thing (1974: 51).

Finally, it has also been discussed that the quest for freedom is indeed frightening because of what Amanda Wingfield in Williams' most famous The Glass Menagerie calls "tyranny of time". The characters in the two plays discussed are preoccupied with the quest for youth, but time waits for nobody. old man like Boss Finley conceals his aging and weakness by having a mistress. Older women like Serafina Delle Rose and Princess Kosmonopolis nurture their illusion of eternal youth by spending as much time as possible with younger men like, respectively, Chance Wayne and Alvaro Mangiacavallo. Meanwhile, the young women in these plays are depicted as being impatient to get the men they fall in love with. It should be noted that women need marriage to survive is the most pervasive theme in American drama of the 20s and 30s (Bonin, 1975: 2) that still echoes in both plays. Whether the playwright intended or not, a pattern emerges: the male characters evade their problems instead of facing the ruthlessness of life or simply makes a quick, practical solution; whereas the female characters tend to hold fast to their romantic Southern beliefs that value family life although they have to live in falsification. These women are unlikely to succeed in their search for freedom, but they do not escape in cowardly fashion like the male counterparts. Berkowitz (1992: 96) contends that Williams typically ends his play with "the happiest available" if "the happiest imaginable" is not possible. As it is, Williams speaks of the socio-psychological problems that continue to exist even in today's society where people grapple with their search for freedom in a false heaven by means of wealth and sex.

\section{References}

Benson, Lou. Images, Heroes, and SelfPerceptions. New Jersey: Prentice Hall, 1974.

Berkowitz, Geraald M. American Drama of the Twentieth Century. London: Routledge, 1997.

Bigsby, C.W.E. A Critical Introduction to Twentieth Century American Drama 2, London: Metthuen, 1984.

Blum, John $\mathrm{M}$ et al. Eds. The National Experience: A History of the United States. New York: Wadsworth Publishing, 1993.

Bonin, Jane F. Major Themes in Prize-Winning American Drama. New York: Rowman \& Littlefield, 1975.

Boxill, Roger. Tennessee Williams. Hamburg: Metthuen, 1987.

Choudhuri, A.D. The Face of Illusion in American Drama. Atlantic Higlands: Humanity Press, 1979.

Falk, Signi. Tennessee Williams. New York: Twayne Publishers, 1961.

Goldstein, Malcolm. "Body and Soul on Broadway" Modern Drama 7.4 (1965): 411-421. Project MUSE. Web. 9 Jul. 2014. <http://muse.jhu.edu/> 
Greenfield, Thomas A. Work and Work Ethic in American Drama 1920 - 1970. Columbia: University of Missouri Press, 1982.

Hirsch, Foster. A Portrait of the Artists: The Plays of Tennessee Williams. Port Washington: Kennikat, 1979.

Jackson, Esther M. The Broken World of Tennessee Williams. Madison: Wisconsin University Press, 1966.

Kennedy, Roger G. Rediscovering America: Journeys through Our Forgotten Past. Boston: Houghton Mifflin, 1992.

Monte, Christopher F. Beneath the Mask: An Introduction to Theories of Personalities. New York: Wiley and Sons, 1987.

Pradhan, N. S. Modern American Drama. New Delhi: Arnold Heinemann, 1978

Scanlan, Tom. Family, Drama, and American Dramas. Westport, Connecticut: Greenwood Press, 1978.

Schulte-Sasse, L. "Fixing the Nation's Problem: When a Sweet Bird of Youth Crosses the Line". Cultural Critique 43 (1999):13-37. http://doi.org/10.2307/1354487

Siegel, Janice. "Tennessee Williams' "Suddenly Last Summer" and Euripides' "Bacchae"'. International Journal of the Classical Tradition 11.4 (2005): 538-570. Web 14 March 2016. Stable URL: http://www.jstor.org/stable/30222012

Sievers, W. D. Freud on Broadway. New York: Hermitage House, 1970.

Skaggs, M. M. The Folks of Southern Fiction. Georgia: University of Georgia Press, 1972.

Spoto, Donald. The Kindness of Strangers: The Life of Tennessee Willimas. Boston: Luttle Brown, 1985.
Starnes, Leland. "The Grotesque Children of the Rose Tattoo" In Essays on Modern American Drama. Ed. Dorothy Parker. Toronto , Buffalo : University of Toronto Press, 1987.

Tejaswani, Kadavakollu. "The Flight: Depiction of the American Dream in Tennessee Williams' Sweet Bird of Youth" IOSR Journal of Humanities and Social Science 8. 6 (Mar. - Apr. 2013): 5659 e-ISSN: 2279-0837, p-ISSN: 22790845. www.Iosrjournals.Org

Timpane, John. "Weak and Divided People': Tennesse Williams and the Written Women" In Feminist Rereadings of Modern Drama. Ed. J. Schlueter. London and Toronto: Associated University Press, 1989.

Williams D. and S. Mead. Tennessee Williams: An Intimate Biography. New York: Arbor House, 1983.

Williams, Tennessee. The Rose Tattoo. London: Penguin, 1955. . Sweet Bird of Youth. New York: Penguin, 1958; rpr. New York: Penguin Book Ltd., 1978. . Memoirs. New York: Doubleday, 1975. 